\title{
Toward integrated and sustainable waste management system in University of Malaya: UM zero waste campaign
}

\author{
Sumiani Yusoff* \\ Dean, Sustainability Science Research Cluster, Universiti Malaya, 50603, Kuala Lumpur, Malaysia.
}

\begin{abstract}
With the escalated increase in municipal solid waste (MSW) generation in Malaysia reaching a shocking 38,000 ton/day in 2017 , a sustainable waste management system is much desired. Nationwide, there are 176 landfills but only 8 are sanitary landfill with the rest are open dumpsites. In the campus of University of Malaya, UM Zero Waste Campaign (UM ZWC) was introduced in 2011 to start a long-term campaign to achieve an integrated and sustainable waste management model and ultimately a zero-waste campus. Since year 2015, UM ZWC is fully funded by Sustainability Science Research Cluster of UM (Susci) as one of the living labs of UM as well as by JPPHB under the RMK-11 budget. UM ZWC operating projects including in house composting center, food waste segregation scheme, research composting emission and waste characterization, anaerobic digestion (AD), used clothes collection program, wood waste separate collection, e-waste collection and drop-off recycling collection were initiated under the campaign. Since the inception of the project in 2011 until December 2017, almost over 620 tons of solid waste has been diverted from disposal in landfill with composting, $\mathrm{AD}$, recycling, re-use and energy recovery. A roadmap of UM ZWC was drawn up in 2013, with a goal to achieve $60 \%$ landfill diversion by year 2040. In the next 5-10 years, UM ZWC plays a vital role to formalize the recycling collection in UM and further increase the organic waste recycling with green waste shredding and composting. Besides environmental benefits (pollution prevention and carbon emission reduction), UM ZWC brings various benefits such as academic research opportunities for UM, contribute in UM LCCF (Low carbon city framework) target and serve as platform to improve students soft skills and entrepreneur skill. Multi stakeholders participation, support form top management and industrial collaboration are the key factors that are able to drive the development of a sustainable waste management model in UM campus.
\end{abstract}

\section{Introduction}

Solid waste can be referred as unwanted waste is that derived from the animal and human activities. It is also can be generated from industrial, institution, residential, commercial, construction and demolition activities. Solid waste can be classified based on its contents including materials such as paper, plastics, glass, metal and organic waste. Moreover, it also can be categorized based on hazard potential incorporated with radioactive, flammable, toxic or non-toxic. While solid waste management is defined as discipline associated with control of generation, storage, collection, transportation, processing and disposal of solid waste materials in the best way to deal with the range of public health, conservation, economic and other environmental considerations. The main goal of solid waste management is to minimize and eliminate adverse effects on human health and environment to aid economic development and quality of life.

Generally, solid waste composition in Malaysia largely constitute of municipal solid waste (MSW) 64\% with the remaining consisting of industrial waste, commercial waste, and construction waste [12]. In 2007, with a population more than 25 million, Malaysian households produce approximately 18,000 tons of household waste every day. Rapidly growing population, improved quality of life and rising economic growth are the factors that contribute challenges to the management of solid waste [11]. With significant improvement of living standards, it is expected that solid waste generation increases over the years without any transformation in the attitudes and behavior of Malaysians in managing their waste. With the utilization of plastic and paper materials especially in packaging where those materials become easily dispensable to the consumers, solid waste generation increases at uncontrollable rate $[13,2]$. The least favored disposal method is landfilling, as waste should be separated and treated (physical, chemical, or biological treatment), but unfortunately these options are costly and timeconsuming [14].

Landfill is the most economical and hence most common MSW disposal method in Malaysia. Nationwide, there are 176 operating landfills but only 11 of them are sanitary landfills with seven in Peninsula Malaysia, one in Sabah and three in Sarawak. Besides the operating landfills, there are 114 closed landfills in the country which required post closure treatment and management for at least 30 years. The total capacity of MSW disposed in the current 176 operating landfills is more than 30,000 ton/day and the total size of operating

\footnotetext{
다responding author: sumiani@um.edu.my
} 
landfills is 2,528.2 ha. In total, the size of operating and closed landfills is $3,446.2$ ha, which is $0.01 \%$ of Malaysia total land area. In Malaysia, approximately $93.5 \%$ of municipal solid waste (MSW) is sent without sorting to the landfill or open dumpsites that have no gas recovery, and only $5.5 \%$ of MSW is being recycled and $1.0 \%$ composted [1]. Table 1 shows the present number of operating and non-operating solid waste disposal sites in Malaysia.

Table 1. Number of operating and non-operating solid waste disposal sites in Malaysia.

\begin{tabular}{|c|c|c|c|c|}
\hline State & $\begin{array}{l}\text { Operatin } \\
\text { g non- } \\
\text { sanitary } \\
\text { landfill } \\
\text { sites }\end{array}$ & $\begin{array}{l}\text { Operatin } \\
\text { g } \\
\text { sanitary } \\
\text { landfill } \\
\text { sites }\end{array}$ & $\begin{array}{l}\text { Non- } \\
\text { operatin } \\
\mathrm{g} \text { landfill } \\
\text { sites }\end{array}$ & $\begin{array}{c}\text { Tota } \\
1\end{array}$ \\
\hline Johor & 12 & 2 & 23 & 37 \\
\hline Kedah & 8 & 1 & 6 & 15 \\
\hline Kelantan & 13 & 0 & 6 & 19 \\
\hline Melaka & 2 & 0 & 5 & 7 \\
\hline $\begin{array}{l}\text { Negeri } \\
\text { Sembilan }\end{array}$ & 7 & 0 & 11 & 18 \\
\hline Pahang & 16 & 0 & 16 & 32 \\
\hline Perak & 17 & 0 & 12 & 29 \\
\hline Perlis & 1 & 0 & 1 & 2 \\
\hline $\begin{array}{l}\text { Pulau } \\
\text { Pinang }\end{array}$ & 2 & 0 & 1 & 3 \\
\hline Sabah & 19 & 0 & 2 & 21 \\
\hline Sarawak & 46 & 6 & 14 & 66 \\
\hline Selangor & 5 & 4 & 14 & 23 \\
\hline $\begin{array}{l}\text { Terenggan } \\
\mathrm{u}\end{array}$ & 8 & 0 & 12 & 20 \\
\hline $\begin{array}{l}\text { Federal } \\
\text { Territory } \\
\text { of Kuala } \\
\text { Lumpur }\end{array}$ & 0 & 0 & 7 & 7 \\
\hline $\begin{array}{l}\text { Federal } \\
\text { Territory } \\
\text { of Labuan }\end{array}$ & 1 & 0 & 0 & 1 \\
\hline TOTAL & 157 & 13 & 130 & 300 \\
\hline
\end{tabular}

Solid waste has constantly been an issue particularly in the amount of solid waste generated [15]. The increasing affluence leads to uncontrollably high amount of solid waste production despite the potential of source separation and recycling in Malaysia. Lack of public conscientious in today's modern lifestyle has resulted to increasing amount of waste generated and disposed at landfills especially when it comes to packaging, as these materials are dispensable to them [4]. Education and individual upbringing contribute considerably towards environmental awareness, how society perceives the issue, as well as how they decide on their daily behavior, particularly in managing solid waste [3]. Besides the influence of socio-economic factors, perception of infinite resources with no observable environmental consequences to the public led to over-consumption, which produces unnecessary waste ultimately. Without the support and commitment from households, local authorities, private concessionaires, and other stakeholders in organizing solid waste, source separation and recycling practice would be a major challenge.

It was reported that in 2003, the amount of solid waste generation per capita per day ranged between 0.5 up to $0.8 \mathrm{~kg}$ but recently it had increase to between 0.5 to $2.5 \mathrm{~kg}$, especially in the major city such as Kuala Lumpur and Petaling Jaya [7]. Table 2 shows that food waste and organic material are found to have highest portion in solid waste generated in Malaysia which ranges between $32 \%$ to $68.4 \%$.

Table 2. The Material Composition of Municipal Solid Waste Obtained from Various Studies and Site (Chua et al, 2001)

\begin{tabular}{|c|c|c|c|c|c|c|c|c|c|}
\hline $\begin{array}{l}\text { Comp } \\
\text { onent }\end{array}$ & $\begin{array}{l}20 \\
01\end{array}$ & $\begin{array}{l}20 \\
01\end{array}$ & $\begin{array}{l}20 \\
02\end{array}$ & $\begin{array}{l}20 \\
03\end{array}$ & $\begin{array}{l}20 \\
04\end{array}$ & $\begin{array}{l}20 \\
05\end{array}$ & $\begin{array}{l}20 \\
05\end{array}$ & $\begin{array}{l}20 \\
07\end{array}$ & $\begin{array}{l}20 \\
10\end{array}$ \\
\hline $\begin{array}{l}\text { Food } \\
\text { waste } \\
\& \\
\text { organi } \\
\text { cs }\end{array}$ & $\begin{array}{l}68 \\
.4\end{array}$ & 32 & $\begin{array}{c}56 \\
.3\end{array}$ & $\begin{array}{l}37 \\
.4\end{array}$ & $\begin{array}{c}49 \\
.3\end{array}$ & 45 & $\begin{array}{l}47 . \\
5\end{array}$ & 42 & $\begin{array}{c}43 \\
.5\end{array}$ \\
\hline $\begin{array}{l}\text { Mix } \\
\text { plastic } \\
\text { S } \\
\end{array}$ & $\begin{array}{l}11 \\
.8\end{array}$ & 16 & $\begin{array}{l}13 \\
.1\end{array}$ & $\begin{array}{l}18 \\
.9\end{array}$ & $\begin{array}{l}17 \\
.1\end{array}$ & 24 & $\begin{array}{l}\mathrm{N} \\
\mathrm{A}\end{array}$ & $\begin{array}{l}24 \\
.7\end{array}$ & $\begin{array}{c}25 \\
.2\end{array}$ \\
\hline $\begin{array}{l}\text { Mix } \\
\text { paper }\end{array}$ & $\begin{array}{l}6 . \\
3 \\
\end{array}$ & $\begin{array}{l}29 \\
.5 \\
\end{array}$ & $\begin{array}{l}8 . \\
2 \\
\end{array}$ & $\begin{array}{l}16 \\
.4 \\
\end{array}$ & $\begin{array}{l}9 . \\
7 \\
\end{array}$ & 7 & $\begin{array}{l}18 . \\
5\end{array}$ & $\begin{array}{l}12 \\
.9 \\
\end{array}$ & $\begin{array}{l}22 \\
.7 \\
\end{array}$ \\
\hline $\begin{array}{l}\text { Textil } \\
\text { es }\end{array}$ & $\begin{array}{l}1 . \\
5 \\
\end{array}$ & $\begin{array}{l}3 . \\
4 \\
\end{array}$ & $\begin{array}{l}1 . \\
3 \\
\end{array}$ & $\begin{array}{l}3 . \\
4 \\
\end{array}$ & $\begin{array}{l}\mathrm{N} \\
\mathrm{A}\end{array}$ & $\begin{array}{l}\mathrm{N} \\
\mathrm{A} \\
\end{array}$ & $\begin{array}{l}2.1 \\
3 \\
\end{array}$ & $\begin{array}{l}2 . \\
5 \\
\end{array}$ & $\begin{array}{l}0 . \\
9\end{array}$ \\
\hline $\begin{array}{l}\text { Rubbe } \\
\text { r \& } \\
\text { Leath } \\
\text { er }\end{array}$ & $\begin{array}{l}0 . \\
5\end{array}$ & 2 & $\begin{array}{l}0 . \\
4\end{array}$ & $\begin{array}{l}1 . \\
3\end{array}$ & $\begin{array}{l}\mathrm{N} \\
\mathrm{A}\end{array}$ & $\begin{array}{l}\mathrm{N} \\
\mathrm{A}\end{array}$ & $\begin{array}{l}\mathrm{N} \\
\mathrm{A}\end{array}$ & $\begin{array}{l}2 . \\
5\end{array}$ & $\begin{array}{l}\mathrm{N} \\
\mathrm{A}\end{array}$ \\
\hline Wood & $\begin{array}{l}0 . \\
7\end{array}$ & 7 & $\begin{array}{l}1 . \\
8\end{array}$ & $\begin{array}{l}3 . \\
7\end{array}$ & $\begin{array}{l}\mathrm{N} \\
\mathrm{A}\end{array}$ & $\begin{array}{l}\mathrm{N} \\
\mathrm{A}\end{array}$ & $\begin{array}{l}4.4 \\
1\end{array}$ & $\begin{array}{l}5 . \\
7\end{array}$ & $\begin{array}{l}\mathrm{N} \\
\mathrm{A}\end{array}$ \\
\hline $\begin{array}{l}\text { Yard } \\
\text { waste }\end{array}$ & $\begin{array}{l}4 . \\
6\end{array}$ & $\begin{array}{l}\mathrm{N} \\
\mathrm{A}\end{array}$ & $\begin{array}{l}6 . \\
9\end{array}$ & $\begin{array}{l}3 . \\
2\end{array}$ & $\begin{array}{l}\mathrm{N} \\
\mathrm{A}\end{array}$ & $\begin{array}{l}\mathrm{N} \\
\mathrm{A}\end{array}$ & $\begin{array}{l}2.7 \\
2\end{array}$ & $\begin{array}{l}\mathrm{N} \\
\mathrm{A}\end{array}$ & $\begin{array}{l}\mathrm{N} \\
\mathrm{A}\end{array}$ \\
\hline $\begin{array}{l}\text { Ferro } \\
\text { us }\end{array}$ & $\begin{array}{l}2 . \\
7\end{array}$ & $\begin{array}{l}3 . \\
7\end{array}$ & $\begin{array}{l}2 . \\
1\end{array}$ & $\begin{array}{l}2 . \\
7\end{array}$ & 2 & 6 & $\begin{array}{l}\mathrm{N} \\
\mathrm{A}\end{array}$ & $\begin{array}{l}5 . \\
3\end{array}$ & $\begin{array}{l}2 . \\
1\end{array}$ \\
\hline Glass & $\begin{array}{l}1 . \\
4\end{array}$ & $\begin{array}{l}5 . \\
5 \\
\end{array}$ & $\begin{array}{l}1 . \\
5\end{array}$ & $\begin{array}{l}2 . \\
6\end{array}$ & $\begin{array}{l}3 . \\
7\end{array}$ & 3 & $\begin{array}{l}\mathrm{N} \\
\mathrm{A}\end{array}$ & $\begin{array}{l}1 . \\
8\end{array}$ & $\begin{array}{l}2 . \\
6\end{array}$ \\
\hline $\begin{array}{l}\text { Pamp } \\
\text { ers }\end{array}$ & $\begin{array}{l}\mathrm{N} \\
\mathrm{A}\end{array}$ & $\begin{array}{l}\mathrm{N} \\
\mathrm{A}\end{array}$ & $\begin{array}{l}\mathrm{N} \\
\mathrm{A}\end{array}$ & $\begin{array}{l}5 . \\
1\end{array}$ & $\begin{array}{l}\mathrm{N} \\
\mathrm{A}\end{array}$ & $\begin{array}{l}\mathrm{N} \\
\mathrm{A}\end{array}$ & $\begin{array}{l}\mathrm{N} \\
\mathrm{A}\end{array}$ & $\begin{array}{l}3 . \\
81 \\
\end{array}$ & $\begin{array}{l}\mathrm{N} \\
\mathrm{A}\end{array}$ \\
\hline Other & $\begin{array}{l}2 . \\
1\end{array}$ & $\begin{array}{l}1 . \\
9\end{array}$ & $\begin{array}{l}8 . \\
4\end{array}$ & $\begin{array}{l}5 . \\
3 \\
\end{array}$ & $\begin{array}{l}18 \\
.2 \\
\end{array}$ & 15 & $\begin{array}{l}21 . \\
93\end{array}$ & $\begin{array}{l}2 . \\
6\end{array}$ & $\begin{array}{l}1 . \\
8\end{array}$ \\
\hline Total & $\begin{array}{l}10 \\
0 \\
\end{array}$ & $\begin{array}{l}10 \\
0 \\
\end{array}$ & $\begin{array}{l}10 \\
0 \\
\end{array}$ & $\begin{array}{l}10 \\
0 \\
\end{array}$ & $\begin{array}{l}10 \\
0 \\
\end{array}$ & $\begin{array}{l}10 \\
0 \\
\end{array}$ & $\begin{array}{l}10 \\
0 \\
\end{array}$ & $\begin{array}{l}10 \\
0 \\
\end{array}$ & $\begin{array}{l}10 \\
0 \\
\end{array}$ \\
\hline
\end{tabular}

Food wastes produce greenhouse gases (GHG) emissions and have an influence on climate change [6]. Generally, these emissions have been identified as an critical environmental concern in the waste sector [8]. In Asian countries, it is estimated that the largest increase of food waste generation could be ranged from 278 to 416 million tones that can contribute to global anthropogenic emissions ranging from 8 to $10 \%$ [16]. Apart from the waste treatment, GHG emissions from waste handling, transportation and operation of 
machinery are also significant especially due to the utilization of fossil-based energy. Indirect GHG saving potential via materials and energy recovery from waste management must be recognized [5].

Food waste composting can be considered as one of the most appropriate approaches for treating biodegradables waste components, also one of the potential waste management elements to divert waste generated to landfill, while simultaneously recycling organic materials by converting them into a beneficial product. The potential of practicing composting are huge as $70 \%$ of Malaysian wastes are wet waste, which are not easily recycled as the dry waste. In Malaysia, the average components of MSW are quite similar with the largest categories consisting of food waste (45\%), plastic (24\%) followed by paper (7\%), iron (6\%) and lastly $3 \%$ for glass and others [9]. Food waste is a main component of MSW which can lead to the emission of odorous compounds and can affect the quality of leachate from landfill and others.

\section{Literature review}

University of Malaya is a public university located in Kuala Lumpur. It is a multidisciplinary Research University that has more than 20,000 students and 2000 academic staff with 14 faculties/academy, 3 academic centres, 11 research institutes and clusters which covers the whole spectrum of learning from the Arts, Sciences and Humanities. In University of Malaya, the Sustainability Science Research Cluster (SuSci) is one of the entity that play a catalytic role to promote research and initiatives in a holistic and comprehensive perspective to resolve the problem that is relevant to global sustainability, social and human life system. SuSci also have its origin in the concept of development as recommended by the World Commission on Environment and Development (WCED) in 1987 and aims to achieve status society and sustainable and balanced life between physical development and maintenance environment. Amongst the many research programs under Susci, the Living Lab projects, promotes translational and problem solving especially in promoting UM eco campus initiatives and environmental conservation and reducing campus environmental impact.

Being a top university and committed toward holistic excellence, UM launched the University of Malaya Eco Campus Blueprint as a sign of commitment toward campus sustainability performance and has targeted 8 thrust areas for improvement where the Zero Waste Campaign (UM ZWC) is one of the university's longest and most consistent endeavors [19]. It is also unique due to the bottom-up and top-down synergy that characterizes its development. It has the following objectives such as to develop policy and innovation systems to divert organic waste (from disposal in landfill) for nutrient (composting) and energy recovery (anaerobic digestion), to streamline recycling activities and strategize efforts to increase recycling rates, to create awareness and inculcate best practices of waste separation at source among campus communities, serve as a long term campaign to achieve an integrated waste management model and ultimately a zero waste campus, initiate projects, research projects and schemes such as the Green Bag Scheme, an in-house composting centre, an anaerobic digestion project, recycling collection system for e-waste, used textiles and wood waste, composting emission study and others.

The project was incepted by final year students in the Environmental Engineering program in 2009 led by Associate Prof. Dr. Sumiani Yusoff who advocated the needs to address the challenges, posed by the inevitable environmental liabilities in waste management and carefully identified the major drawbacks concerning the low environmental performance of MSW management in the country. They initiated a chain of activities to development of recycling management system in the faculty with minimal cost. In July 2009, VeeCYCLE, a student group was formed to run an integrated recycling project in Faculty of Engineering. The project established a recycling management model which has resulted in the development of an organized and effective waste and recyclables collection system in the faculty. 45 sets of an integrated waste and recyclables collection facility called PRO Bin were introduced to replace the existing rubbish receptacles in the faculty. It facilitates the good practice of separation at source.

It was set-up to spearhead the development of a more sustainable waste management model in the UM campus and ultimately achieve the status of a zero-waste campus. This campaign is a daily operation which is seven days a week without interruption that requires observation and a strong commitment to ensuring that all the waste on campus is managed in an orderly manner and in accordance with the establishment of the procedures. This field also requires cooperation from the café operators in UM due to estimated average of $40 \%$ of food waste from the overall composition of waste in UM. Hence, organic and inorganic waste are managed by UM ZWC and the university's assets and service department, JPPHB, reducing monthly almost 15-20 tons of waste to landfill, while reducing cost and reducing environmental impacts through reduction in carbon emissions and footprint and leachate contamination avoidance. Hence UM ZWC has promoted the concept of sustainable consumption and production by converting food and green waste into valuable resources such as compost and biogas. Other endeavor includes educational campaign and workshops about waste management, segregation at source and recycling. On a more long-term level, UM ZWC has drawn up a roadmap for the UM Development Unit to achieve 15\% landfill diversion by year 2020 (phase 1), 30\% by year 2030 (phase 2) and $60 \%$ by year 2040 (phase 3 ) while phase 1 have been achieved by UM ZWC which is $15 \%$ landfill diversion by year 2020. The integrated solid waste management system set up through the UM ZWC Living Lab projects has strengthen the green growth agenda toward sustainable development and environmental conservation in UM campus by empowering the campus community through a 
systematic, concerted, and action-oriented problem solving translational research initiative.

\section{Methodology}

Solid waste generated in UM campus is collected by fixed collection systems. UM communities are supposed to deposit the waste at the locations specified by the Department of Development \& Estate Management (JPPHB) every day of the week and will be collected by a specific time. These generated solid wastes are transported by vehicles which can be categorized as collection and haulage vehicles [10]. Collection vehicles collect the waste in where it is generated and then transfer and dispose to the disposal facility which is UM ZWC located near the Damansara Gate. The waste will be segregated by the workers to reduce the volume and pollution potential for landfill sites. Moreover, UM ZWC used a Takakura composting method as a meaningful processing technology for the bulk of the degradable organic fractions. The composting method was eventually evolved into aerated static piles with capacity of $4-5$ ton/month $(90 \%$ food waste and $10 \%$ green waste, by weight). In 2013, Cowtec ${ }^{\circledR}$ anaerobic digestion (AD) $100 \mathrm{~kg} /$ day unit was installed after research collaboration with $\mathrm{CH}$ Green Sdn Bhd. With the AD facility, about 1 ton of food waste is converted to biogas and bio-fertilizer every month. Until end of year 2014, about 120 ton of organic waste had been composted or treated anaerobically by UM ZWC.

2014 is an improvement year for UM ZWC with more collaboration with industries to establish separate collection of various waste streams, collaboration with academic institutions for research, more appearance in environmental conferences, expo and media, and strengthening rapport from UMCARES and JPPHB. The public private partnership (PPP) between UM ZWC and several private entities had resulted in successful separate collection of waste streams for recycling/landfill diversion. At the beginning of 2014, UM ZWC collaborated with Life Line Clothing (LLC) Sdn Bhd to introduce a used clothes collection program which had expanded rapidly in year 2014 that saw the collection of more than 20 ton of used clothes and waste textile. At the end of the year, ZWC formed partnership with TSP Waste Management to kick off a wood waste separate collection system for energy recovery which is implemented successfully with about 5-6 ton/month capacity in the first month.

The support from UM top management, especially DVC (Development) to UM ZWC, is very important to ensure the success of the PPP. For instance, the sites approval to LLC to place the used clothes collection bins and cooperation to collect wood waste separately in a dedicated open top Ro-Ro bin for wood waste recycling. The DVC (Development), Prof. Faisal Rafiq had allocated budget for the upgrading of ZWC facilities in year 2015 such as new ZWC building, green waste shredder, a weighbridge station and composting center. The UM ZWC cabin serve as resource center, site treatment facility and meeting room for visitors to UM
ZWC site. Under DVC (Development), JPPHB assists UM ZWC in the provision of several manual workers, waste and recycling data as well as collection receptacles for food waste such as bins and bags. Moreover, this data collection practice is also contributing to UM LCCF (Low Carbon City Framework) project.

On the other hand, various programs were carried out to enable the implementation of the projects, including awareness publicity program for students and staffs, capacity building program for the kitchen staffs and cleaners, discussion and meeting with strategic partners both UM and external bodies as well as several site visits to enhance the students' knowledge in waste management. The programs promote the development of communication, information, negotiation and consultation skills among the students. The projects are poised to further strengthen their roles in realizing IWM model by enabling on site, in-house organic waste treatment operation and expanding the coverage of recycling collection points (PRO Bin).

In 2017, UM ZWC develops an Intelligent Recycle Center (IRC) with Coindex $\mathrm{Sdn}$ Bhd to promote behavior and inculcate best practice of recyclables dropoff with this innovative automated recycle center located at lecture hall A\&B PASUM. With the new recycling system, UM communities are able to send their source segregated recyclables to the center for conversion into green points which can be used to claim goodies such as compost, USB pendrive, t-shirt and redeemable discounted price in participating cafeteria in UM. This kind of reward-based interactive recycling innovation can bring multiple benefits and contribution to positive social behavioral change (recycling habit) and resource conservation with increase of recycling rate. Furthermore, in near future the IRC can serve as thematic environmental center in UM campus with a galleria of environmental related information to the corridor of lecture hall building. The IRC is anticipated as the cornerstone to develop a formal recycling separate collection in the campus of UM, which is one of the primary concepts of integrated waste management.

\section{Result and Discussion}

Data collection and analysis is very important in development of integrated waste management plan. With the weighbridge station installation in July 2015, UM $\mathrm{ZWC}$ is able to capture the waste disposal data. The complete/comprehensive data that UM ZWC fully possesses are food waste collected for composting or anaerobic digestion, green waste collected for composting, wood waste collected for energy recovery, waste textiles collected for reuse/recycle, E-waste collected at UM ZWC site for recycling/recovery, recyclable materials sorted at UM ZWC site and UM transfer station and residual waste disposal data.

UM ZWC coordinated and gathered all the data from different parties. With the data, tonnage per year was calculated as below (Table 3). From the data, it shows the increasing of total waste was diverted for treatment and recycling by UM ZWC from 2012 until 2016. The 
increasing factor is due to the improvement of the project by collaborating with textile industry to introduced used clothes collection program which had expanded rapidly in year 2014 that saw the collection of more than 20 ton of used clothes and waste textile. At the end of the year, UM ZWC formed partnership with TSP Waste Management to kick off a wood waste separate collection system for energy recovery which is diverted with about 5-6 ton/month from landfill. Used clothes and waste textiles are collected separately with ten (10) units of "drop-off" collection bins while wood waste is collected by JPPHB in separate open top bin for energy recovery in a paper mill.

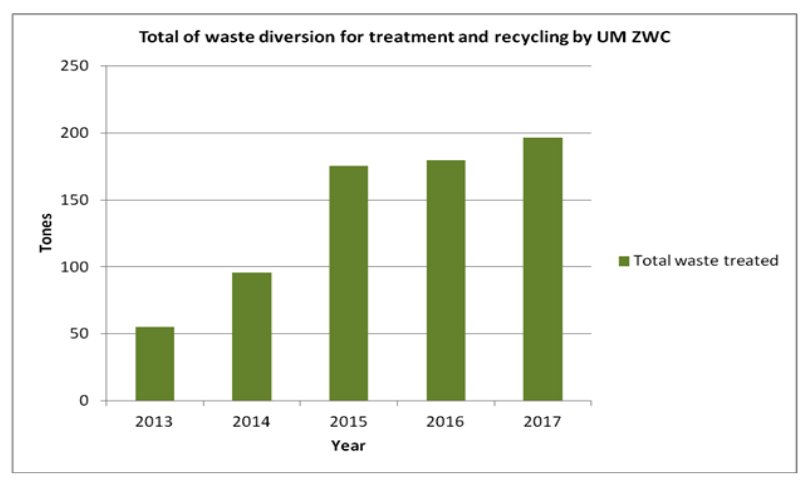

Fig.1. Total of waste diversion for treatment and recycling by UM ZWC (2012-2016)

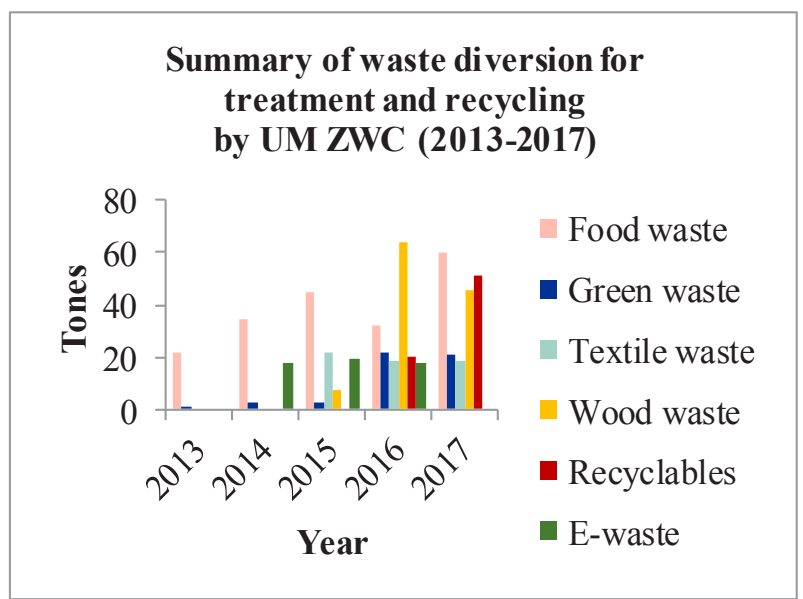

Fig.2. Summary of waste diversion treatment and recycling by UM ZWC (2012-2016)

Institutionalization of separate organic waste collection and treatment system in UM is the key to achieve integrated waste management system. Green Bag Scheme is the first program to kick-start the food waste segregation practice in the campus. Organic waste made up almost half of total waste generated in UM campus and thus the recovery and treatment of organic waste is very important to increase recycling rate (landfill diversion rate). In UM, green waste is segregated at source by gardeners and collected separately using a small lorry of JPPHB in a daily basis. About 2 ton of green waste is generated from UM campus everyday and all the green waste is collected and loaded separately in two open top Ro-Ro bins (refer figure 2). It can be shown that the amount of food waste has increased until 2014. For 2015, the amount of treatment and recycling of food waste had decrease due to the closing of dining hall in all residential college of UM campus. UM ZWC had the difficulty to obtain the food wastes that have been segregated. Thus, UM ZWC organized the food waste segregation program to all cafeterias in UM campus with the help of $\mathrm{OSH}$ (occupational safety and health unit in UM) by providing the transparent plastics bags that is only to be used for food waste. In 2016, the amount of food waste had risen and was strengthen with the publishing of the Code of Practice Food Waste Segregation at Source guidelines by UM ZWC.

For the recyclables material separation for recycling, it was and is still an up hilling challenge for UM ZWC as the current practice of recycling collection by informal players poses significant hindrance. However, with the persistent efforts by UM ZWC and JPPHB, collection of recycling data is improving from time to time and the introduction of the Intelligent Recycling Center (IRC) this year will hopefully further boost the development of recycling in UM campus. In term of economic, UM ZWC has been saved more than RM 97, 758 from January 2012 until December 2016 (refer Table 3). The monetary saving included the collection fee and landfill gate fee. While for the environmental saving, UM ZWC has been saved almost 726.46 ton $\mathrm{CO}_{2}$-eq. The reduction in economic and environmental aspects due to the waste recovery and composting process that is diverted biodegradable are wastes and composted. [17, 18].

Table 3. Economic and environmental cost saving of UM ZWC as of 2011- 2017

\begin{tabular}{|c|c|c|c|c|c|c|c|c|}
\hline $\mathrm{No}_{1}$ & Type of waste & Tonnege & $\begin{array}{l}\text { No, oftips } \\
\text { reduced }\end{array}$ & $\begin{array}{l}\text { Collection fee } \\
\text { saved } \mid \text { RM }\end{array}$ & $\begin{array}{l}\text { Landfill ggtefefer } \\
\text { stved (RM) }\end{array}$ & $\begin{array}{l}\text { Total monetitey } \\
\text { soving (RM) }\end{array}$ & 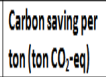 & $\begin{array}{l}\text { Calbonstaving } \\
\mid \text { ton } \mathrm{CO}_{2}: \mathrm{eap} \mid\end{array}$ \\
\hline 1. & Foodwaste & 275 & 138 & 48,125 & 15,125 & 63,250 & 2,359 & 648.73 \\
\hline 2. & Greenwaste & 54.75 & 37 & 12,775 & 3,011 & 15,786 & 1.563 & 85.57 \\
\hline 3. & Woodwaste & 162,03 & 81 & 28,355 & 8,912 & 37,267 & 1.552 & 251.47 \\
\hline 4. & Textlewaste & 74,86 & 50 & 17,467 & 4,117 & 21,585 & 0,616 & 46.11 \\
\hline \multirow[t]{2}{*}{5.} & Recyclablematerials & 121.42 & 81 & 28,331 & 6,678 & 35,009 & 0.048 & 5.83 \\
\hline & Total & 6888.06 & 387 & 135,053 & 37,843 & 172,899 & & $1,037,71$ \\
\hline
\end{tabular}

\section{Summary/ Concluding Remarks}

The UM ZWC project, comprising of waste segregation and composting biodegradable waste, is a good example of a highly integrated approach accounting for the different elements of solid waste project sustainability. The project also has been made a clear distinction between how to enable improved environment influences performance and outcome of the project, and how the project impacts positively on UM social, economic and ecological environment. Ultimately, by making efforts in implementing food waste management systems, the future perspective of food waste could create opportunities in handling energy demands and moving toward sustainable development. The sustainability of UM ZWC is important for UM's reputation locally and internationally as an example of eco campus which 
emphasizes on academic excellence and whilst promoting sustainable development. UM ZWC has successfully developed several key projects that serve as milestone to boost recycling rate in the campus. In the next 5-10 years, UM ZWC plays a vital role to formalize the recycling collection in UM and further increase the organic waste recycling with green waste shredding and composting. Besides environmental benefits (pollution prevention and carbon emission reduction), UM ZWC brings various benefits such as academic research opportunities for UM, contribute in UM LCCF (Low carbon city framework) target and serve as platform to improve students soft skills and entrepreneur skill. Multi stakeholder's participation, support form top management and industrial collaboration are the key factors that are able to drive the development of a sustainable waste management model in UM campus.

\section{References}

1. Agamuthu P, Fauziah SH, Kahlil K., Evolution of solid waste management in Malaysia: impacts and implications of the solid waste bil,. J Mater Cycles. 11:96-103. (2009).

2. A. Malahkahmad, M.Z.Z. Che Mohd Nasir, S.R. Mohammed Kutty, M. Hasnain Isa. Solid waste characterization and recycling potential for University Technology PETRONAS academic buildings. Am. J. Environ. Sci., 6 (5), pp. 422 427(2010)

3. Brian, L., Craig, H., James, L., Lisa, K., Richard, W., Tim, S., Reducing Food Loss and Waste Installment 2 of 'Creating A Sustainable Food Future', World Resource Institute, Washington, DC. (2013)

4. D. Asmawati, A.K. Nor Ba'yah, Y. Fatimah. A study on the knowledge, attitudes, awareness status and behaviour concerning solid waste management. Procedia Soc. Behav. Sci., 18, pp. 643-648 (2011)

5. Gentil, E., Christenen, T.H., Aoutin, E., Greenhouse Gas Accounting and Waste Management, Waste Management \& Research, 27, 696-706 (2009)

6. IPCC, In: Metz, B., Davidson, O.R., Bosch, P.R., Dave, R., Meyer, L. A., (Eds), Contribution of Working Group III To the Forth Assessment Report of The Intergovernmental Panel on Climate Change. Cambridge University Press, Cambridge, United Kingdom and New York, USA. (2007)

7. Kathirvale, S., Muhd Yunus, M. N., Sopian, K., Samsuddin, A. H., Energy potential From Municipal Solid Waste in Malaysia. Renewable Energy, 29, 559-567 (2003)
8. Liamsanguan, C., Cheewalas.H., The Holistic Impact of Integrated Solid Waste Management on Greenhouse Gases Emissions in Phuket, Journal of Cleaner Production, 16, 865-1871 (2008)

9. McDougall, F., White, P., Franke, M., Hindle, P. Integrated Solid Waste Management: A Life Cycle Inventory. ( $2^{\text {nd }}$ Eds), Blackwell Publishing (2001)

10. Onn Chiu Chuen, Sumiani Yusoff et. al. Working towards A Sustainable Means of Campus Transportation. In University of Malaya Living Lab: Transforming Research into Action, 1, Sustainability Science Research Cluster University of Malaya (2018)

11. Shekdar, A.V., Sustainable Solid Waste Management: An Integrated Approach for Asian Countries, Waste Management 29 (4), 1438-1448. (2009)

12. Sustainable Waste Management Cycle (EASWMC), EU-Perak Solid Waste Management Plan (EU-PSWMP). Perak, Malaysia (2009)

13. M. Abdul Jalil, Sustainable development in Malaysia: a case study on household waste management. J. Sustain. Dev., 3 (3) (2010), pp. 91102 (2010)

14. M.S. Grodzinska-Jurczak, Management of industrial and municipal solid wastes in Poland. Resour. Conserv. Recycl., 32 (2), pp. 85-103. (2001)

15. X. Gellynck, R. Jacobsen, P. Verhelst, Identifying the key factors in increasing recycling and reducing residual household waste: a case study of the Flemish region of Belgium, J. Environ, Manag., 92 (10), pp. 2583-2590 (2011)

16. Saer, A., Lansing, S., Davitt, N.H., Graves, R.E., Life cycle assessment of a food waste composting system: environmental impact hotspots. J. Cleaner Prod. 52, 234-244 (2013)

17. Sumiani Yusoff (Ed) UM Living Lab: Transforming Research into Action. 1 and 11. Sustainability Science Research Cluster University of Malaya (2018)

18. Sumiani et. al. University of Malaya Zero Waste Campaign: Integrated and Sustainable Waste Management. In University of Malaya Living Lab: Transforming Research into Action 1. Sustainability Science Research Cluster University of Malaya, pp 71-85 (2018).

19. Sumiani et al. University of Malaya Eco-Campus Blueprint. University of Malaya. Kuala Lumpur, Malaysia (2016) 